\title{
GAMBARAN HISTOPATOLOGI GASTER MENCIT HIBRID F1 (C3HxAJ) YANG DIINOKULASI TUMOR ADENOCARCINOMA MAMMA SECARA INTRAVENA, INTRAPERITONIAL DAN SUBKUTAN
}

\author{
dr. Tias Pramesti Griana \\ Jurusan Biologi, Fakultas Sains dan Teknologi UIN Maliki Malang \\ Email : tiaspram_esti@yahoo.co.id
}

\begin{abstract}
The aim of the current study was to know if adenocarcinoma mamma tumor can be appear at the stomach of $F 1$ hybrid mouse (C3HxAJ) that innoculated adenocarcinoma mamma's tumor via antravenous, intraperitoneal, and subcutaneus. Methods : The study was experimentaly using posttest control group design, to examine the pylorus mucosa thickness, the number of metaplasia, hyperplasia, and inflammatory cell. Result : There were no metaplasia and hyperplasia but inflammatory cell has been found. Analize of the pylorus mucosa thickness and the number of inflammatory cell by Oneway ANOVA showed there was no significant different of control group and manipulated group (intravenous, intraperitoneal and subcutaneus) ( $p>0.05)$. Conclution : Adenocarcinoma mamma's tumor has been not found at the stomach of F1 hybrid mouse (C3HxAJ) that innoculated with via intravenous, intraperotoneal and subcutaneus.

Keyword : tumor transplantation, adenocarcinoma mamma, C3H mouse, gaster
\end{abstract}

\section{Pendahuluan}

Profil kesehatan Indonesia 2008 dari Departemen Kesehatan Republik Indonesia melaporkan bahwa kanker payudara menduduki urutan pertama dari 10 penyakit kanker pada pasien rawat inap di rumah sakit pada tahun 2004-2007. Data dari SIRS (Sistem Informasi Rumah Sakit) juga menunjukkan bahwa jumlah kasus kanker payudara pada tahun 2007 mencapai 8.277 kasus (16,65\%). Sedangkan data dari Globocan (Global Burden of Cancer) pada tahun 2008 dari International Agency for Research on Cancer (IARC) menyatakan insidens kanker payudara di Indonesia 36,2/100.000 perempuan dan angka kematian mencapai 18,6/100.000 perempuan (Briani, 2011).

Hampir 50\% pasien kanker payudara mengalami metastasis selama hidupnya. Data hasil otopsi melaporkan adanya insiden metastase jauh yang tidak terdeteksi. Kematian pada kanker payudara disebabkan penyebaran (metastase) kanker ke seluruh tubuh. Metastase kanker payudara sering terjadi pada paru (70\%), hati (60\%), tulang (25\%) dan sisanya pada sumsum tulang, otak, ovarium, mata, medulla spinalis dan gaster (Miol, 2003; Titi et al, 2010).

Kanker payudara adalah kanker yang paling banyak menyebabkan metastasis, tetapi metastase ke gaster merupakan kejadian yang jarang. Dari otopsi, didapatkan insiden kejadian metastase ke traktus gastrointestinal sekitar 4-35\%. Metastase ke gaster dideteksi sebesar $0,3-18 \%$ pada pasien kanker payudara yang telah menyebar ke banyak organ. Di negara-negara eropa, frekuensi penyebaran ke gaster dilaporkan sebesar 3.2-7.4\% pada kasus yang diotopsi. Sebuah penelitian dari Japan Centra Revuo Medicina antara tahun 1983 sampai 2008 didapatkan hanya terjadi 1 kasus saja. Metastase ke gaster dapat terjadi jauh bertahun-tahun setelah terapi awal yang diberikan, tetapi pada umumnya setelah adanya penyebaran yang luas dengan prognosis yang buruk. (Ghirarduzzi et al, 2010; Pectasides et al, 2009). Pada studi kasus yang dilakukan oleh Yamaguchi et al (2009), dilaporkan seorang penderita kanker payudara yang metastase ke gaster 7 tahun setelah di lakukan mastektomi. Penyebaran ke gaster teridentifikasi setelah adanya metastase ke paru dan pleura. Hasil biopsi menunjukkan jenis adenocarcinoma.

Penelitian kanker difokuskan pada faktor inisiasi karsinogenesis. Berbagai macam usaha dilakukan untuk memindahkan kanker dari hewan coba yang satu ke hewan coba yang lain, baik dalam satu spesies maupun dari spesies yang berbeda, melalui inokulasi tumor hidup. Didapatkan hasil positif terutama pada hewan coba mencit, dan telah jelas bahwa dalam inokulasi tumor dibutuhkan sel kanker yang hidup. Tyzzer dan Litte yang melakukan 
eksperimen pada tahun 1921 menyimpulkan, bahwa terdapat dasar-dasar genetik yang berperan dalam mekanisme penerimaan atau penolakan transplantasi sel kanker, dan hal ini menunjukkn adanya penurunan sifat gen Mendelian yang mendasari kompatibilitas host terhadap transplantasi, sehingga mencit inhibrid memberikan kontribusi yang besar pada pencapaian penelitian ini (Kaliss, 1965). Mencit $\mathrm{C} 3 \mathrm{H}$ adalah salah satu model binatang coba yang populer untuk pembentukan tumor mamma (payudara). Strain ini membawa virus tumor mamma $\mathrm{C} 3 \mathrm{H}$ tipe $\mathrm{S}$ dan betina hasil perkawinan menunjukkan tipe dengan insiden yang tinggi dalam pertumbuhan tumor pada usia 11 bulan (Sakata et al, 2011).

Tumor dapat ditransplantasikan dari hewan coba yang satu dengan hewan coba yang lainnya, selama kedua hewan coba, baik donor maupun resipien memiliki susunan gen yang identik (isogenic). Transplantasi tumor ke resipien dengan strain yang berbeda dari donor, dalam satu spesies, dapat menghasilkan penolakan karena resipien tidak memiliki gen yang identik dengan gen donor (allogenic). Hasil transplantasi yang berbeda antara resipien allogenic dan resipien isogenic diperankan oleh gen yang mengkode antigen transplantasi yang disebut major histocompatibility complex (MHC) antigent. Pada sel normal, telah teridentifikasi lebih dari 50 gen yang menentukan fungsi pengenalan dari protein asing oleh sel-sel T. Gen-gen ini teridentifikasi pada peran mereka dalam mengkode protein, termasuk dalam mekanisme transplantasi tumor. MHC antigen merupakan protein membran sel yang diklasifikasikan dalam dua grup, MHC klas I (MHC-I) dan MHC klas II (MHC-II). Pada manusia protein ini didefinisikan sebagai human leucocyte antigen (HLA). Produksi antibodi yang membutuhkan pengambilan dan pembelahan protein penghancur (proteolitik) dari antigen dan fragmen-fragmen ini harus dipresentasikan ke sel $\mathrm{T}$ yang terikat reseptor. MHC antigen berperan sebagai reseptor. MHC-I ditemukan pada semua tipe sel, sedangkan MHC-II hanya terdapat pada sel-sel spesifik dari sistem imun. MHC-I pada sel kanker sangat penting terutama untuk pengenalan oleh sel T (King, 2000).

Teori genetik dari transplantasi tumor mencit sebagai model hewan coba adalah bahwa pertumbuhan jaringan transplantasi ditentukan oleh berbagai gen yang disebut gengen histokompatibilitas atau disingkat sebagai gen $H$. Pertumbuhan permanen dan progresif terjadi jika dan hanya jika semua gen histokompatibilitas pada kromosom jaringan yang ditanam ada pada host (Snell dan Stimpfling, 1965).

Mencit $\mathrm{C} 3 \mathrm{H}$ digunakan secara luas untuk eksperimen onkologi dan terapi neoplasma. Alasan penggunaan mencit $\mathrm{C} 3 \mathrm{H}$ sebagai hewan coba penelitian tumor dikarenakan kompatibilitasnya yang luas terhadap berbagai macam model tumor. Kompatibilitas semakin tinggi pada mencit inhibrid dengan sifat lebih dari $99 \%$ homozigot pada generasi ke 20 atau lebih dari perkawinan kakak-adik (setiap generasi yang dikawinkan akan mereduksi $19 \%$ sifat heterozigot yang dimiliki). Hampir $88 \%$ mencit $\mathrm{C} 3 \mathrm{H}$ hibrid betina kompatibel terhadap tumor jenis adenocarcinoma mamma (Corbett et al, 2002; Festing, 2004).

Eksperimen yang pernah dilakukan di Laboratorium Patologi Eksperimental Bagian Patologi Anantomi Fakultas Kedokteran Universitas Indonesia oleh Pringgoutomo (1998), yang merupakan transplantasi sel tumor adenocarcinoma mamma mencit hibrid F1 (C3HxAJ) secara intravena, menunjukkan bahwa ada metastase sel tumor tersebut ke organ paru, hepar dan ginjal. Transplantasi sel carcinoma mamma secara subkutan menghasilkan metastase di paru, hepar, dan kelenjar limfe regional (Menon dan Teicher, 2002). Sedangkan inokulasi sel kanker secara intraperitonial yang dilakukan oleh Sugiura (1953), menghasilkan lesi metastase pada beberapa tempat, yaitu disekitar pankreas, lien, intestin, peritonium dari organ hepar, diafragma, omentum, limfonodus, dan paru.

Berdasarkan penelitian diatas, dilakukan penelitian eksperimental invivo dengan hewan coba mencit untuk mendapatkan data yang terkait dengan pengaruh metode transplantasi sel tumor adenocarcinoma mamma terhadap struktur histopatologi gaster.

\section{Bahan dan Cara Kerja}

Desain penelitian yang digunakan dalam penelitian ini adalah rancangan eksperimental murni dengan bentuk posttest control group design untuk mengetahui perubahan histopatologi organ gaster mencit hibrid F1 (C3HxAJ) yang diberi perlakuan berupa injeksi tumor adenicarcinoma mamma secara intravena, intraperitonial dan subkutan.

Sampel hewan coba yang digunakan peneliti berjumlah 25 ekor, 4 ekor sebagai 
kontrol dan 7 ekor untuk masing-masing kelompok perlakuan. Perlakuan 1 (P1) adalah mencit yang di injeksi sel tumor secara subkutan, perlakuan 2 (P2) adalah mencit yang di injeksi sel tumor secara intraperitonial, sedangkan perlakuan 3 (P3) adalah mencit yang di injeksi sel tumor secara intravena.

Tumor adenocarcinoma mamma diambil dari mencit donor yaitu mencit $\mathrm{C} 3 \mathrm{H}$ yang mengandung tumor adenocarcinoma mamma yang telah dipasase 100-120 kali. Mencit donor diambil dari Laboratorium Patologi Anatomi FKUI. Sedangkan mencit resipien dan kontrol adalah mencit hibrid $\mathrm{F} 1$ (C3HxAJ) yang juga diambil dari Laboratorium Patologi Anatomi FKUI. Semua mencit baik donor, resipien maupun kontrol berjenis kelamin betina dengan umur lebih dari 2,5 bulan dan berat badan 18-22 gram. Kondisi mencit sehat.

\section{Hasil dan Pembahasan}

Perubahan ketebalan mukosa gaster, banyaknya sel radang, serta adanya metaplasi dan hiperplasi merupakan parameter yang menunjukkan adanya metastase sel adenocarcinoma mamma pada mukosa gaster. Metaplasi dan hiperplasi merupakan tanda terjadinya diferensiasi dari sel normal menjadi sel tumor.
Dari hasil pengamatan didapatkan ratarata ketebalan mukosa gaster pada kelompok kontrol sebesar $239,07 \mu \mathrm{m}$, kelompok subkutan sebesar $265,63 \mu \mathrm{m}$, kelompok intraperitonial sebesar $247,92 \mu \mathrm{m}$, dan kelompok intravena sebesar $289,61 \mu \mathrm{m}$. Berdasarkan uji ANOVA terhadap perhitungan ketebalan mukosa gaster, didapatkan taraf signifikansi antar kelompok $\mathrm{p}>0,05$, yang menunjukkan bahwa tidak ada satu atau lebih kelompok mencit yang memiliki perbedaan signifikan. Struktur epitel mukosa gaster pada semua kelompok mencit (kelompok kontrol, subkutan, intraperitonial dan intravena) dari pengamatan yang dilakukan juga tidak didapatkan perubahan hiperplasi ataupun metaplasi.

Rata-rata jumlah sel radang pada kelompok kontrol sebesar 23, kelompok subkutan sebesar 22, kelompok intraperitonial sebesar 23 dan kelompok intravena sebesar 25,5. Berdasarkan uji ANOVA terhadap perhitungan jumlah sel radang mukosa gaster, didapatkan taraf signifikansi antar kelompok p>0,05 yang menunjukkan bahwa tidak ada satu atau lebih kelompok mencit yang memiliki perbedaan signifikan. Disamping sel radang, juga didapatkan spora jamur disepanjang permukaan mukosa gaster pada seluruh kelompok mencit.

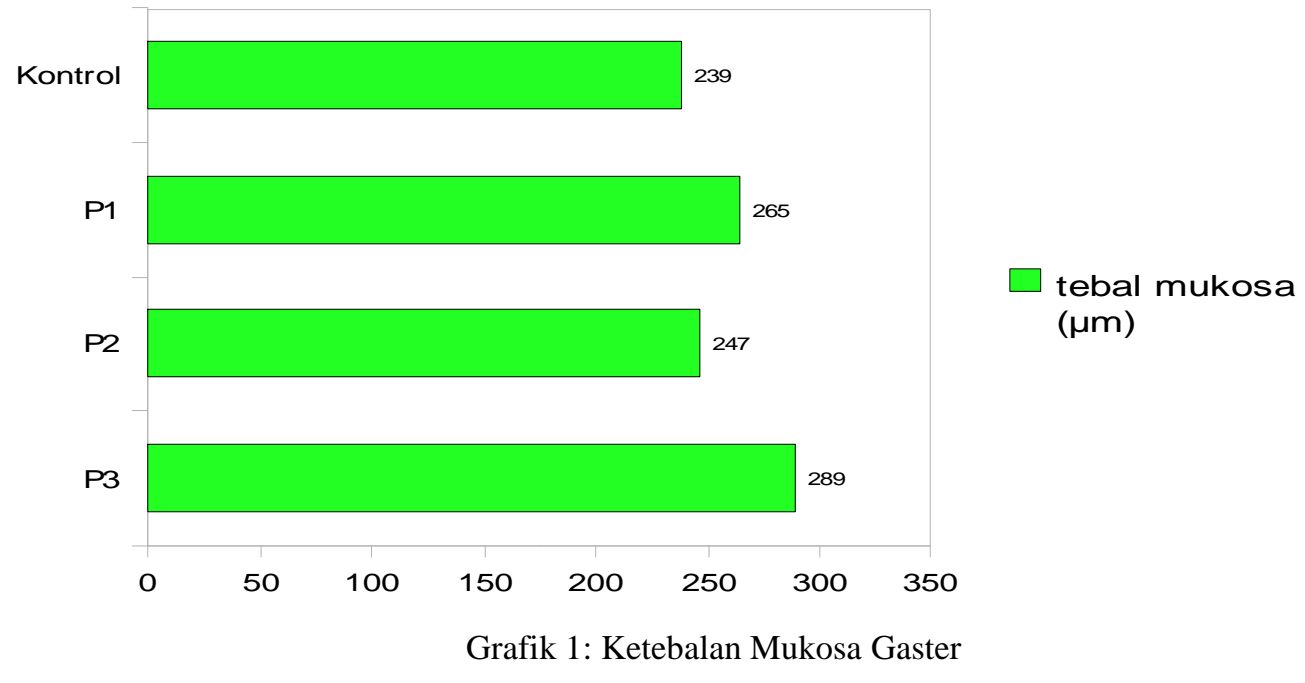




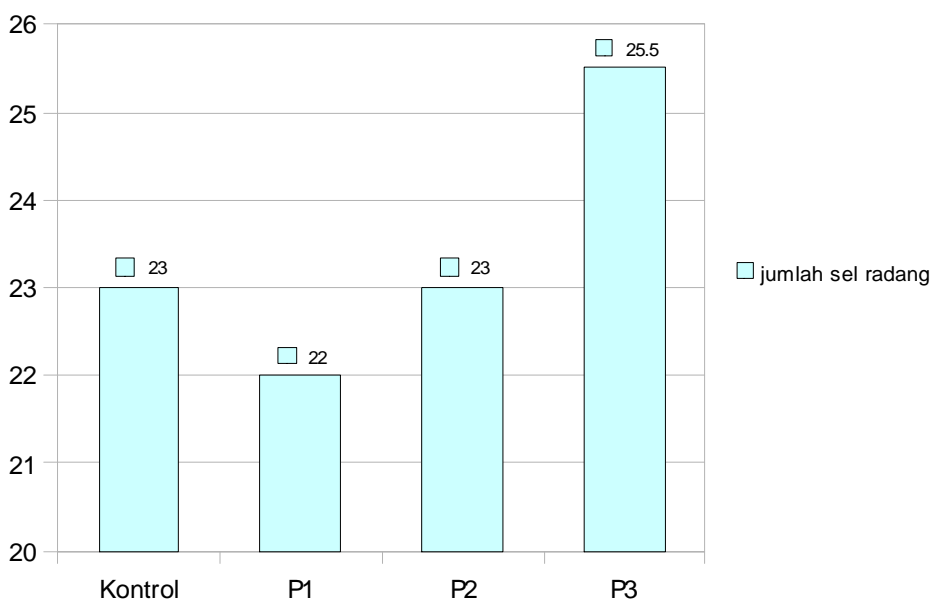

Grafik 2: Jumlah Sel Radang Mukosa Gaster

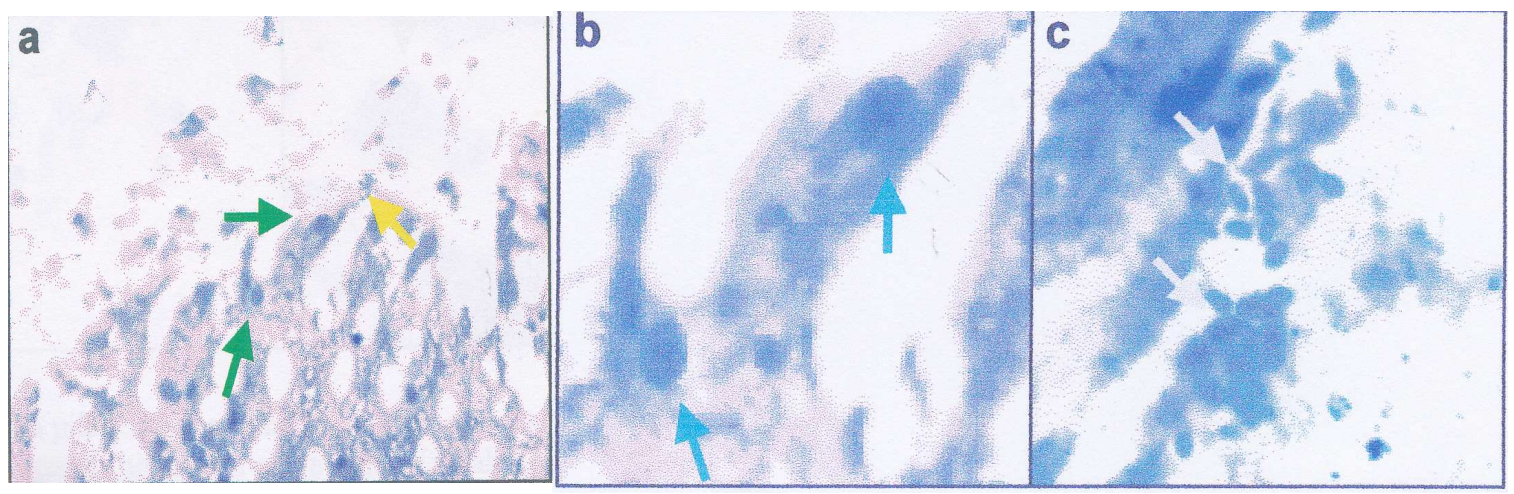

Gambar 1. Gambar mukosa pilorus gaster mencit kontrol. Tampak sel MN (Mononuclear cell)(panah hijau) dan spora jamur (panah kuning). Gambar (a) perbesaran 400x. Gambar (b) dan (c) perbesaran 1000x.

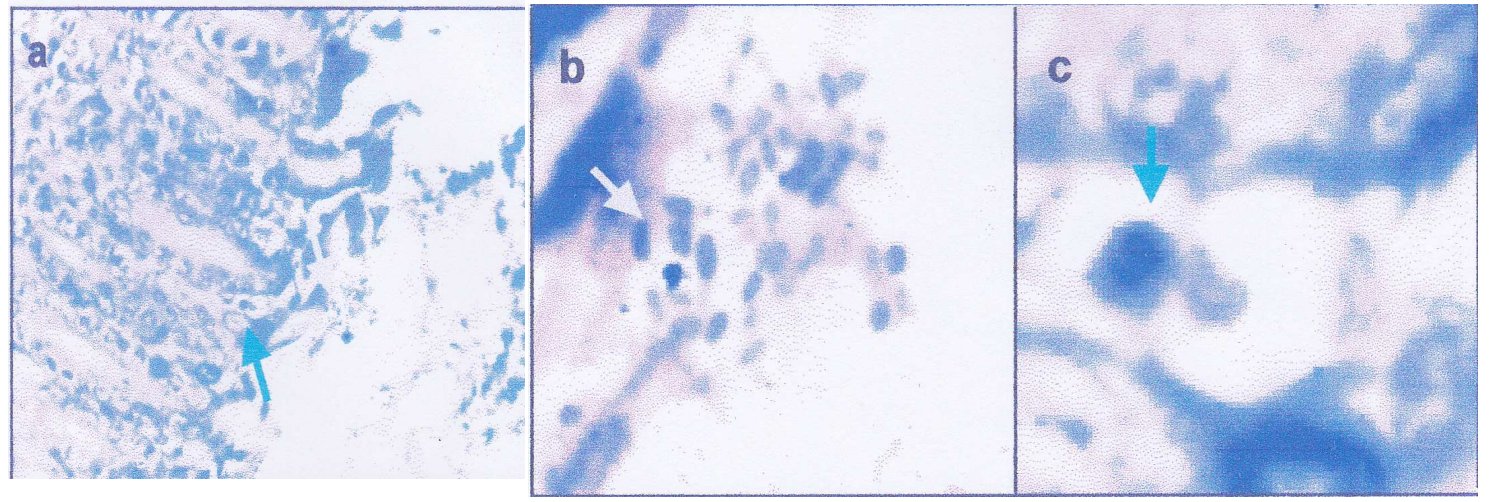

Gambar 1. Gambar mukosa pilorus gaster mencit kelompok subkutan (P1). Tampak sel MN (Mononuclear cell)(panah hijau) dan spora jamur (panah kuning). Gambar (a) perbesaran 400x. Gambar (b) dan (c) perbesaran 1000x. 


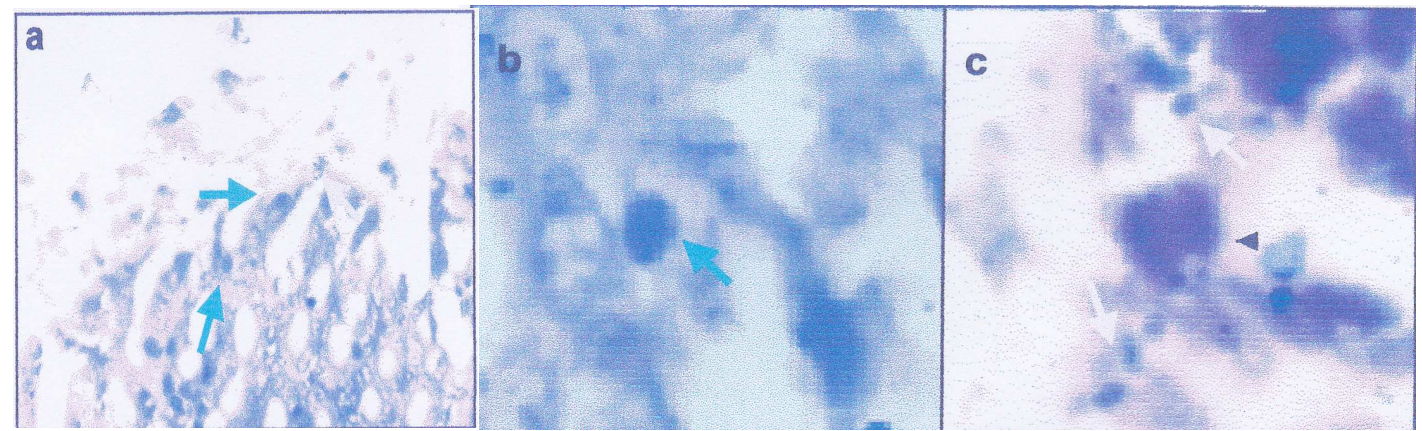

Gambar 2. Gambar mukosa pilorus gaster mencit kelompok intraperitonial (P2). Tampak sel MN (Mononuclear cell)(panah hijau) dan spora jamur (panah kuning). Gambar (a) perbesaran 400x. Gambar (b) dan (c) perbesaran 1000x.
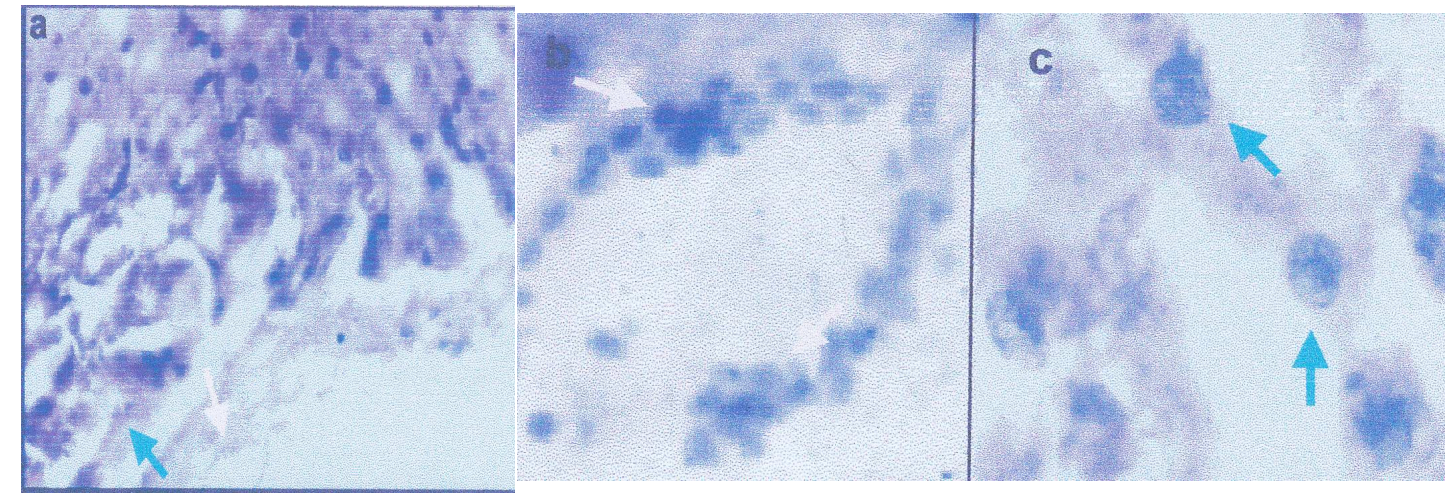

Gamabar 3. Gambar mukosa pilorus gaster mencit kelompok intravena (P3). Tampak sel MN (Mononuclear cell)(panah hijau) dan spora jamur (panah kuning). Gambar (a) perbesaran 400x. Gambar (b) perbesaran 1000x.

Tidak adanya perbedaan tebal mukosa dan jumlah sel radang pada gaster, baik antara kelompok kontrol dengan kelompok perlakuan inokulasi subkutan, intraperitonial dan intravena, serta dan tidak didapatkannya metaplasi dan hiperplasi disemua jenis kelompok mencit disebabkan tidak terjadi perubahan struktur lapisan epitel permukaan, lamina propria dan lapisan muskularis pada mukosa gaster. Tidak terjadinya perubahan struktur ini bisa jadi disebabkan sel kanker yang diinokulasikan tidak mencapai gaster atau ada kegagalan dalam salah satu atau lebih tahapan mekanisme metastase sel kanker.

Didalam mekanisme metastase sel kanker, terjadi tahapan proses yang setiap tahapnya tidak boleh gagal untuk menghasilkan metastase tempat jauh. Proses ini dimulai dari pertumbuhan progresif neoplasma primer, vaskularisasi, invasi, ekstravasasi, terhindar dari pertahanan host, dan pertumbuhan progresif dari sel kanker yang telah mencapai tempat metastase. Dalam setiap tahap mekanisme ini, dipengaruhi oleh berbagai faktor yang menentukan kemana sel kanker akan metastase.

\section{Kegagalan tahapan metastase pada inokulasi sel tumor adenocarcinoma mamma secara subkutan}

Untuk menghasilkan metastase ke gaster pada inokulasi sel tumor adenocarcinoma mamma secara subkutan, harus terjadi mekanisme tahapan metastase yang lengkap. Injeksi sel tumor hidup secara subkutan pada mencit yang isogenic dengan mencit donor menghasilkan pertumbuhan kanker primer pada tempat injeksi (King, 2000). Pertumbuhan kanker primer akan menjadi progresif jika proses angiogenesis tidak terhambat, serta persediaan nutrisi bisa terjamin. Beberapa growth factor, seperti basic fibroblast growth factor (bFGF), vascular endothelial cell growth factor (VEGF), tumor growth factor- $\alpha$, dan angiogenin, mempengaruhi proses angiogenesis. Dua faktor angiogenic (bFGF dan VEGF) ini diproduksi oleh berbagai sel maligna. Sel 
tumor sebenarnya tidak menghasilkan faktor angiogenik sendiri, melainkan membutuhkan stimulus dari sel mast dan makrofag untuk dapat mengeluarkan faktor angiogenik, sehingga jika stimulus sel mast dan makrofag tidak adekuat, maka proses angiogenesis akan terganggu (Nicolson, 1995). Begitu pula pada persediaan nutrisi, mencit resipien yang diberi pola diet yang besar akan menghasilkan pertumbuhan tumor primer yang baik, karena asupan perotein yang besar sangat diperlukan dalam pertumbuhan tumor hasil transplantasi (Hoag dan Dickie, 1965; Sugiura, 1953). Sebaliknya, pola diet yang kurang protein tidak akan menghasilkan pertumbuhan tumor primer.

Sel-sel tumor primer pada jaringan subkutan yang terlepas harus dapat masuk ke pembuluh limfe perifer, atau pembuluh darah sekitarnya melalui proses invasi. Invasi pada pembuluh limfe dipengaruhi oleh kemampuan adesi sel tumor pada selaput basalis limfatik, pelepasan enzim degradatif dan penembusan amuboid kedalam saluran. Proses invasi pada pembuluh darah ditentukan oleh kemampuan motilitas dan kemampuan adesi sel tumor pada sel endotel. Kemampuan motilitas sel kanker dipengaruhi oleh faktor motilitas autokrin dan faktor motilitas parakrin. Faktor motilitas autokrin, seperti glikosaminoglikan dan asam hialuronidase disekresi oleh sel tumor untuk menginduksi motilitas sel tumor itu sendiri. Faktor motilitas autokrin tidak spesifik bekerja pada sel tumor tertentu, karena molekul ini didapatkan pada berbagai tipe sel tumor yang ditransplantasi. Sedangkan faktor motilitas parakrin spesifik untuk sel tumor tertentu. Hal ini menyebabkan besar kecilnya kecenderungan invasi sel tumor ke pembuluh limfe atau pembuluh darah spesifik (Levinel dan Stracke, 1995; Robbins dan Kumar, 1997). Jika kecenderungan menginvasi pembuluh limfe atau pembuluh darah kecil, maka ada kemungkinan sel tumor tidak dapat metastase dan hanya menimbulkan lesi primer saja pada tempat inokulasi.

Sebelum sel tumor ekstravasasai, terjadi interaksi sel tumor didalam pembuluh darah dengan sel endotel. Sel endotel mensintesa dan mensekresi berbagai molekul, seperti kolagen tipe IV, laminin, fibronektin, dan proteoglikan yang disebut molekul matriks ekstraseluler. Sel endotel mengekspresikan molekul adesi yang akan berikatan dengan reseptor dipermukaan sel tumor, sehingga sel tumor melekat pada endotel. Perlekatan ini dilanjutkan dengan penghancuran struktur membran basal oleh proteolitik yang disekresi oleh sel kanker, sehingga sel kanker dapat migrasi keluar dari pembuluh darah. Molekul adesi yang dapat berikatan dengan reseptor sel tumor tidak sama untuk setiap jenis kanker, sehingga ekstravasasi hanya terjadi pada pembuluh darah yang spesifik untuk sel tumor. Hal inilah yang menyebabkan kecenderungan metastase ke organ tertentu pada suatu jenis sel kanker (Nicolson, 1995).

Setelah ekstravasasi, sel tumor akan membentuk pertumbuhan sekunder. Sel tumor metastasis baru dapat hidup jika proses angiogenesis seperti yang terjadi pada sel tumor primer dapat berhasil dengan baik. Hal inipun juga dipengaruhi oleh lingkungan mikro dari jaringan tempat sel tumor metastase (Fidler, 1997).

Kegagalan tahapan mekanisme metastase
pada inokulasi sel tumor adenocarcinoma
mamma secara intraperitonial
Ketika sel tumor diinjeksikan kedalam intraperitonial, sel tumor akan menyebar bersama dengan cairan intraperitonial. Didalam cairan intraperitonial, sel tumor dapat mitosis dan tumbuh tanpa adanya stroma dan pembuluh darah, meskipun didapatkan beberapa sel limfoid didalam cairan intraperitonial akibat reaksi imun host. Cairan intraperitonial mengandung growth factor yang menopang pertumbuhan sel tumor. Sel kanker dapat tumbuh dipermukaan peritonium parietal atau visceral membentuk fokus primer. Selanjutnya fokus primer ini akan mengadakan metastase pada jaringan disekitar peritonium. Proses yang mempengaruhi metastase pada transplantasi secara intraperitonial sama dengan pada transplantasi secara subkutan (Kaliss, 1965; Sugiura, 1953).

Kegagalan Tahapan Mekanisme Metastase Pada Inokulasi Sel Tumor Adenocarcinoma Mamma Secara Intraperitonial Intravena

Sel tumor yang diinjeksikan secara intravena akan menghasilkan sel tumor yang bebas berada di sirkulasi. Sel tumor sirkulasi ini tidak membentuk pertumbuhan primer, melainkan langsung didistribusikan ke organ jauh untuk metastase. Teori first pass organ menyatakan bahwa sel tumor sirkulasi atau emboli tumor akan terjebak atau berhenti pada anyaman kapiler yang pertama kali dilewati selama mengalir bersama aliran darah. Hal ini 
menyebabkan metastase sel tumor lebih sering terjadi di daerah yang dekat dengan tempat injeksi atau pada organ yang lebih dulu dimasuki. Teori ini tidak hanya berlaku pada sel tumor yang diinokulasi secara intravena, tetapi secara umum pada sel tumor yang telah mencapai sirkulasi (King, 2000; Nicolson, 1995).

Pada inokulasi sel kanker secara intravena, sel kanker berjalan melalui vena porta, masuk ke organ hepar. Hepar adalah organ yang pertama dilewati sehingga sering menjadi tempat metastase bagi sel kanker yang berjalan melalui vena porta. Jika sel kanker tidak terjebak di hepar, maka sel kanker akan mengikuti aliran darah melalui vena cava inferior menuju jantung dan selanjutnya ke paru. Sel kanker dapat terjebak dan menempel pada jantung atau paru untuk tumbuh. Jika sel kanker tetap bisa melepaskan diri dan mengikuti aliran darah, maka ia akan keluar dari jantung melalui aorta menuju seluruh tubuh. Dari sini sel kanker dapat metastase ke organ mana saja termasuk gaster. Disamping metastase ke organ, sel kanker juga dapat menempel pada endotel pembuluh darah dan tumbuh disana atau menembus ruang interstisial masuk ke pembuluh limfe disekitarnya (King, 2000; Mitchel, 1993). Karena jauhnya rute anyaman kapiler yang harus dilewati sehingga besar kemungkinan sel tumor terjebak atau menempel pada anyaman kapiler ditempat-tempat sebelum mencapai gaster sehingga tidak didapatkan perubahan pada mukosa gaster.

Metastase jauh sel tumor juga ditentukan oleh berhasil tidaknya interaksi antara sel tumor atau "seed" dengan lingkungan mikro host atau "soil" yang menghasilkan metastase sel tumor pada organ spesifik. Hal ini dipengaruhi oleh berbagai faktor yang dihasilkan oleh sel endotel pembuluh darah seperti yang dijelaskan pada konsep invasi dan ekstravasasi sebelumnya serta faktor yang mempengaruhi angiogenesis saat sel kanker mencapai organ metastase (King, 2000; Nicolson, 1995).

\section{Pengaruh Infeksi Terhadap Sel Tumor}

Sel radang yang didapat pada kelompok kontrol dan kelompok perlakuan (intravena, intraperitonial dan subkutan) tidak dapat dinyatakan sebagai akibat invasi sel tumor yang diinokulasikan. Pada sediaan histopatologi gaster mencit kelompok kontrol atau kelompok perlakuan didapatkan sel netrofil atau sel limfosit. Hal ini mungkin dikarenakan proses radang kronis yang kemudian disusul dengan fase akut yang disebabkan oleh infeksi jamur.

Pada beberapa penelitian telah dibuktikan bahwa infeksi yang terjadi sebelum atau menyertai transplantasi tumor akan mempengaruhi pertumbuhan sel tumor. Infeksi yang terjadi menstimulus respon imun host dan meningkatkan kemampuan sel pengenal antigen untuk mengenali antigen yang ada didalam tubuh host, termasuk sel tumor, sehingga fungsi fagositosis sel imun meningkat terhadap sel tumor (Pimm dan Baldwin, 1978). Infeksi jamur yang terjadi pada penelitian ini mungkin juga meningkatkan kemampuan respon imun host terhadap sel tumor.

\section{Kesimpulan}

Dari penelitian ini dapat diambil kesimpulan bahwa inokulasi tumor adenocarcinoma mamma secara intrapertonial, subkutan dan intravena tidak menghasilkan lesi metastase pada organ gaster. Hal ini dimungkinkan karena kegagalan dalam satu atau lebih tahapan metastase serta pengaruh berbagai faktor terhadap tahap angiogenesis, invasi, dan ekstravasasi dari mekanisme metastase yang menyebabkan kecenderungan metastase adenocarcinoma mamma ke organ spesifik, atau akibat infeksi jamur yang mungkin menyebabkan meningkatnya kemampuan respon imun host terhadap sel tumor. Infeksi jamur terjadi akibat kurangnya sterilisasi dari makanan mencit dan pemeliharaan kebersihan kandang.

\section{Daftar Pustaka}

Briani, Farida, 2011. Pemahaman Yang Benar Dan Penanganan Yang Tepat Terhadap Kanker Payudara. http://www.permatacibubur.com/en/see .php?id=gj435\&lang=id (diunduh pada tanggal 15 Mei 2011)

Corbett, Thomas H., et al. 2002. Solid Tumors In Mice:Transplantable Syngeneic Rodent Tumors. Tumors Models in Cancer Research. New Jersey: Humana Press

Festing, Michael F.W. 1998. Inbred Strain of Mice.

http://www.informatics.jax.org/externa 1/festing/mouse/docs/C3H.html. (di unduh pada tanggal 5 Agustus 2004) 
Fidler, Isaiyah J. 1997. Biology of Cancer: Invantion and Metastasis. Cancer: Principles and Practice of Oncology $5^{\text {th }} e d$. Philladelphia: Lippincott-Raven Publishers

Ghirarduzzi, Andrea et al. 2010. Gastric Metastasis from Breast Carcinoma : Report of Three Cases, Diagnostictherapeutic Critical Close Examination and Literature Review. Ann. Itl. Chir; No. 81:141-146

Hoag,Warren G. dan Margaret M. Dickie. 1965. Nutrition. Biology of The Laboratory Mouse. Philladelphia:The Blakiston Company

Kaliss, Nathan. 1965. Transplanted Tumors. Biology of The Laboratory Mouse. Philladelphia: The Blakiston Company

King, Roger J. B. 2000. Cancer Biology $2^{\text {nd }}$ ed. London: Pearson Education Limited.

Levinel, M. D. dan M. L. Stracke. 1995. Stimulation and Regulation of Tumor Cell Motility In Invation and Metastasis. Epithelial-Mesenchimal Interaction In Cancer. Switzerland: Birkhauser Venag Basel

Menon, Krishna dan Beverly A. Teicher. 2002. Metastasis Models. Tumor Models In Cancer Research. New Jersey: Humana Press.

Miol. 2003. Kanker Penyebab Kematian Ke-6 Terbesar di Indonesia. Survey Kesehatan Rumah Tangga Departemen Kesehatan $R I$. http://www.depkes.go.id/index.php op tion $=$ newstask $=$ newsarticle \&sid $=76 \&$ it emid=2 (diunduh pada tanggal 2 Desember 2004)

Mitchel, Malcolm S. 1993. Principles of Tumor Immunology and Their Application to The Biomodulation of Cancer. Medical Oncology $2^{\text {nd }} e d$. New York: McGraw-Hill Book Inc.

Nicolson, G.L. 1995. Tumor Cell Interaction With The Vascular Endothelium And Their Role In Cancer Metastasis. Epithelial-Mesenchimal Interaction In Cancer. Switzerland: Birkhauser Venag Basel

Pectasides et al. 2009. Gastric Metastases Originating from Breast Cancer : Report of 8 Cases and Review of the Literature. Anticancer Research, No.
29: 4759-4764

Pimm, M. V. dan R. W. Baldwin. 1978. Imunology and Immunotherapy of Experimental and Clinical Metastases. Secondary Spread of Cancer. London: Academic Press

Pringgoutomo, Sudarto. 1998. Patologi Eksperimental dan Sumbangannya Kepada Ilmu, Khususnya Patobiologi. Majalah Patologi. Vol.7, No. 4:1-2

Robbins, Stanly L. danVinay Kumar. 1997. Buku Ajar Patologi I Jakarta: EGC

Sakata, Michio et al. 2011. Prevention of Mammary Carcinogenesis in $\mathrm{C} 3 \mathrm{H} / \mathrm{OuJ}$ Mice by Green Tea and Tamoxifen. Asian Pacific $J$ Cancer Prev, No.12:567-571

Snell, George D dan Jack H. Stimpfling. 1965. Genetik of Tissue Transplantation. Biology of The Laboratory Mouse. Philladelphia: The Blakiston Company

Sugiura, Kanematsu. 1953. Tumor Transplantation. Journal Cancer Research. No.27:43

Titi et al. 2010. Isolated Gastrointestinal Metastasis of Breast Carcinoma : Acase Report. Case Reports in Medicine, Vol. 2010

Yamaguchi, Akiko et al. 2009. Gastric Metastasis of Breast Cancer in a Male Patient : Report of a Case. Ann. Cancer Res. Therap. Vol. 17, No. 1: 36-39. 